Annals of Warsaw University of Life Sciences - SGGW

Land Reclamation No 44 (2), 2012: 91-100

(Ann. Warsaw Univ. of Life Sci. - SGGW, Land Reclam. 44 (2), 2012)

\title{
A study of application the modified chalcedonite for underground water treatment
}

MAGDALENA M. MICHEL

Department of Civil Engineering, Warsaw University of Life Sciences - SGGW

\begin{abstract}
A study of application the modified chalcedonite for underground water treatment. The paper presents the results of the research on underground water treatment by manganese dioxide modified chalcedonite (the MDMC-3 variety). The tested material was used as the filling of the gravitation filter. Raw water, taken from the level of the Quaternary and aerated in a pressurized aerator, was supplied for the tested filtration bed from the supply system of the Scientific-Research Waterworks Plant at Warsaw University of Life Sciences - SGGW. The decrease in the iron and manganese concentration as well as colour and turbidity to the level accepted by Directive 98/83/WE was observed. The mass capacities of the filtration bed were $4986 \mathrm{~g} \mathrm{Fe} / \mathrm{m}^{3}$ of the bed and $670 \mathrm{~g} \mathrm{Mn} / \mathrm{m}^{3}$ of the bed. The MDMC-3 material may be classified as a chemically active bed, because it loses its oxidative-sorption capacity during water treatment and can be regenerated with an oxidant. The water-air backwashing is an effectiveness method for cleaning the filtration bed.
\end{abstract}

Key words: underground water treatment, iron and manganese removal, chemically active bed, modified chalcedonite.

\section{INTRODUCTION}

Underground water generally contains iron and manganese compounds. The iron removal technology is simple and usually consists of aeration and filtration (Kowal and Świderska-Bróż 2009). The removal of manganese is technologically more complicated. This consists of trans- forming manganese from the soluble into the insoluble form and separating the generated oxides. The most commonly used method is chemical oxidation combined with filtration or aeration combined with filtration by the materials containing $\mathrm{MnO}_{2}$ (Kowal and Świderska-Bróż 2009). The catalytic beds, being natural manganese ores, consist of $60-95 \%$ $\mathrm{MnO}_{2}$, e.g. Pyrolox, Defeman, G-1 (Kaleta et al. 2009). The different kinds are chemically active beds, which contain manganese oxides on the surface of filtering grains, e.g. Greensand, MZ-10, MTM (Gajowy et al. 2004). During water treatment, the chemically active beds lose the oxidative-sorption capacity, which is their characteristic feature. The capacity can be restored by regeneration of the oxidant. Another example of chemically active beds is clinoptylolite and chalcedonite modified with $\mathrm{MnO}_{2}$ (Anielak 2006; Michel 2011).

Chalcedonite is a sedimentary siliceous rock utilized in the water treatment technology, mostly as an effective filtration material (Michel 2011). It is a very good manganese dioxide carrier. The surface modification changes its chemical properties and the value of the specific surface area. In the work of Michel (2012) three types of manganese dioxide modified chalcedonite (MDMC-1, MDMC-2 and MDMC-3) are presented. 
The chalcedonite coating allowed making the material with the sorption properties in relation to manganese(II) dissolved in water. The maximum sorption capacity of manganese dioxide modified chalcedonite (type MDMC-3) is $1.07 \mathrm{mg}$ Mn per g, which was tested in the static conditions and calculated from the Langmuir's equation (Michel and Kiedryńska 2011). Other studies show that the capacity is variable and strongly depends on the experimental conditions (Michel and Kiedryńska 2012). It should be remembered that the manganese(II) sorption is accompanied by its oxidizing to manganese(III) connected with reduction of manganese(IV) contained in the coat to manganese(III). As a result, the material loses its properties which can be reconstructed by regeneration with the help of an oxidizer, e.g. potassium permanganate.

The aim of this paper was to determine the effectiveness of underground water treatment of MDMC. The MDMC-3 material obtained using the method described by Michel and Kiedryńska (2011) was chosen for the experiment because it was recognized as optimal for the manganese removal process. It was characterized by a satisfactory value of the manganese(II) sorption capacity; however in the flow experiment the MDMC-2 type was more effective than that (Michel 2011). Additionally the method of MDMC-3 making was the least complicated and required neither the use of high temperature nor any caustic substances. Preparation of a large quantity of the MDMC-3 material is technically easier and cheaper than the other MDMC types and the $\mathrm{MnO}_{2}$ coat made on the MDMC-3 is durable.

\section{EXPERIMENTAL}

\section{Experimental Setup and Conditions}

Technological experiment of water conditioning was carried out on the MDMC-3 bed with the height of $0.7 \mathrm{~m}$ and the grain size of $0.8-1.25$. The experiment included single stage gravitational filtration through the bed. Under the main bed there was a supporting layer with the height of $0.2 \mathrm{~m}$ which consisted of quartz gravel with the grain size of 3-10 $\mathrm{mm}$. The scheme of the testing bench is shown in Figure 1. The parameters of the filtration process, backwashing and regeneration of the bed are presented in Table 1. Raw water taken from the level of the Quaternary and aerated in a pressurized aerator was supplied from the supply system of the Scientific-Research Waterworks Plant at Warsaw University of Life Sciences - SGGW for the tested filtration beds. Above the bed, on its particular levels and on the outlet of the column, piezometers were installed to measure the hydraulic resistance of the filtration bed. In the filtration column profile, test cocks for sample collection of the water from different bed's levels were installed. These samples as well as the raw water were analyzed regarding the concentration of the iron and manganese. Additionally, in the raw water and in the treated water, the $\mathrm{pH}$, true colour and turbidity were analyzed. The end of the filtration cycle was determined by: the decrease in the filtration rate to the value of $\leq 6.0 \mathrm{~m} / \mathrm{h}$ (bed clogging) or the overestimation of the permitted values of the quality parameters of domestic water. 


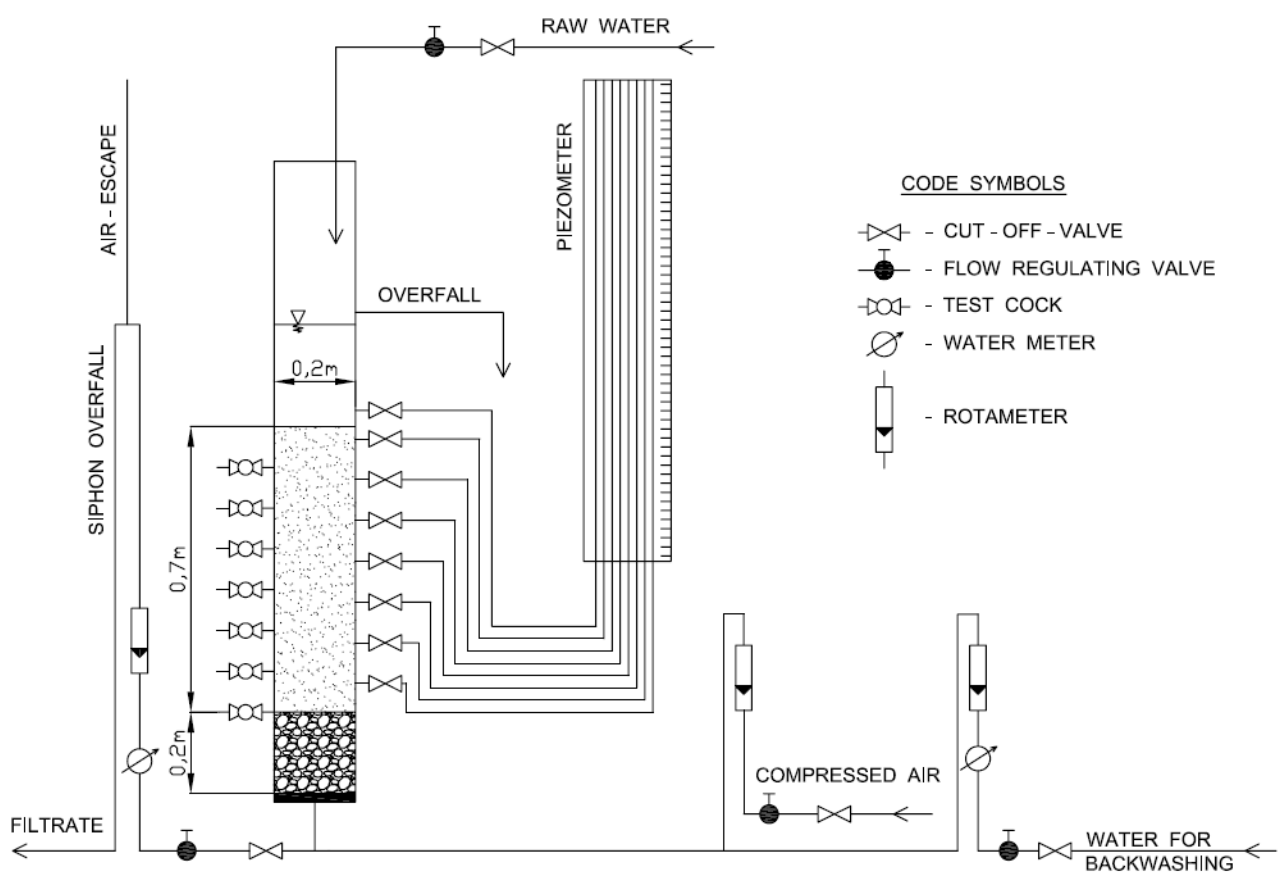

FIGURE 1. The scheme of the testing bench

TABLE 1. Parameters of filtration backwashing and regeneration

\begin{tabular}{|l|c|c|}
\hline Parameter & Unit & Value \\
\hline Filtration rate & $\mathrm{m}^{3} / \mathrm{m}^{2} \mathrm{~h}$ & $6-8$ \\
\hline Time of air backwashing (first step) & $\mathrm{min}$ & 2 \\
\hline Air backwashing rate & $\mathrm{m}^{3} / \mathrm{m}^{2} \mathrm{~h}$ & 90 \\
\hline Time of water backwashing (second step) & $\mathrm{min}$ & 5 \\
\hline Water backwashing rate & $\mathrm{m}^{3} / \mathrm{m}^{2} \mathrm{~h}$ & 60 \\
\hline Bed expansion at water backwashing & $\%$ & 25 \\
\hline Regenerating agent & \multicolumn{2}{|c|}{$0.3 \% \mathrm{KMnO}_{4}$} \\
\hline Dose of regenerating agent & \multicolumn{2}{|c|}{$3.0 \mathrm{~g} \mathrm{KMnO} / \mathrm{L}$ bed } \\
\hline Contact time of agent with bed & $\min$ & 30 \\
\hline
\end{tabular}

\section{Data Treatment}

Mass capacities of the filtration bed regarding iron $M C_{F e}$ [g Fe/L of bed] and manganese (II) $M C_{M n}$ [g Mn/L of bed] were calculated according to the formula:

$$
M C_{F e ; M n}=\frac{\left.\bar{C}_{r}-\bar{C}_{t}\right) V_{t}}{V_{F e ; M n}}
$$

where $C_{r}\left[\mathrm{~g} / \mathrm{m}^{3}\right]$ and $C_{t}\left[\mathrm{~g} / \mathrm{m}^{3}\right]$ are the average concentrations of the component (Fe or $\mathrm{Mn})$ in raw water and treated wa- 
ter, $V_{t}\left[\mathrm{~m}^{3}\right]$ - the volume of treated water, $V_{F e ; M n}[\mathrm{~L}]$ - correspondently the volume of the bed in the zone of deferrization and demanganization.

\section{Analytical Methods}

The iron and manganese were analyzed using the Atomic Absorption Spectrophotometer (PG Instruments) according to the following parameters: for iron analytical line $248.3 \mathrm{~nm}$, slit $0.2 \mathrm{~nm}$, background $\mathrm{D} 2$, working range $0.03-8.0$ $\mathrm{mg} \mathrm{Fe} / \mathrm{L}$ and for manganese analytical line $279.5 \mathrm{~nm}$, slit $0.2 \mathrm{~nm}$, background $\mathrm{D} 2$, working range $0.01-3.5 \mathrm{mg} \mathrm{Mn} / \mathrm{L}$. The $\mathrm{pH}$ measuring was made using the $\mathrm{pH}$ measuring instrument equipped with a gel electrode, the true colour was analyzed using the HACH No 8025 method on the HACH DR 4000 spectrometer, and turbidity was determined on the HACH $2100 \mathrm{~N}$ IS turbidimeter.

\section{RESULTS AND DISCUSSION}

Natural chalcedonite is a very useful material in the water treatment technology. Its grains have a meso- and macroporous structure and irregular surface what corresponds to good filtrating properties of this material. It was stated in Polish scientific branch literature and on the manufacturer's website in the form of letters of reference from different water works plants (Weber and Szambelańczyk 2006; Sozański et al. 2007; Mikrosil...). Moreover, it can be easily affected by coating with an oxide layer. That is why chalcedonit is worth being looked at as filtrating bed. Especially as its resources for exploitation are enough to be exported and the price is comparable to the price of quartz sand used for filtration.

The quality characteristic of the underground water which was used in investigation is presented in Table 2 . The composition of this water is typical,

TABLE 2. Raw underground water characteristics derived from the archives of Scientific-Research Waterworks Plant SGGW

\begin{tabular}{|l|c|c|c|c|}
\hline Parameter & Unit & Value & $\begin{array}{c}\text { Standard } \\
\text { deviation }\end{array}$ & $\begin{array}{c}\text { Limit values } \\
98 / 83 / \mathrm{WE}\end{array}$ \\
\hline Hydrogen ions & $\mathrm{pH}$ & 7.16 & 0.11 & $6.5-9.5$ \\
\hline Conductivity & $\mu \mathrm{S} / \mathrm{cm}$ & 768 & 19 & 2500 \\
\hline Turbidity & $\mathrm{NTU}$ & 1.15 & 0.52 & 1 \\
\hline True colour & $\mathrm{mg} \mathrm{Pt} / \mathrm{L}$ & 25 & 12 & acceptable \\
\hline Alkalinity & $\mathrm{mg} \mathrm{CaCO} / \mathrm{L}$ & 240.8 & 10.8 & - \\
\hline Hardness & $\mathrm{mg} \mathrm{CaCO} / \mathrm{L}$ & 397.9 & 12.2 & - \\
\hline Iron & $\mathrm{mg} / \mathrm{L}$ & 2.67 & 0.21 & 0.2 \\
\hline Manganese & $\mathrm{mg}^{-} \mathrm{L}$ & 0.32 & 0.10 & 0.05 \\
\hline Ammonium cation & $\mathrm{mg} \mathrm{NH}_{4}^{+} / \mathrm{L}$ & 0.52 & 0.13 & 0.5 \\
\hline Nitrate & $\mathrm{mg} \mathrm{NO}_{3} / \mathrm{L}$ & 0.53 & 0.09 & 50 \\
\hline Oxygen demand $\left(\mathrm{KMnO}_{4}\right)$ & $\mathrm{mg} \mathrm{O}_{2} / \mathrm{L}$ & 2.01 & 0.66 & 5.0 \\
\hline Odour and taste & - & acceptable & - & acceptable \\
\hline
\end{tabular}


however partially it exceeds the quality norms for drinking water, determined in Directive $98 / 83 /$ WE. It was characterized by increased concentration of iron and manganese as well as the increased colour and turbidity. The concentration of ammonium cation was low and approached normal. The water contained a small concentration of organic pollution, was of high hardness and increased alkalinity. This water is amenable to treatment. At the Scientific-Research Waterworks Plant - SGGW it is subjected to aeration and filtration on the sand beds covered with $\mathrm{MnO}_{2}$. The concentration of dissolved oxygen let into the water in the technological chain was $2.5-4.0 \mathrm{mg}$ $\mathrm{O}_{2} / \mathrm{L}$. The difference in oxygen concentration followed from the submersible pump effectiveness which depended on the water consumption. The water with these parameters was let onto the filtration bed MDMC-3 on a test bench. The process of filtration allowed the water treatment to the quality level of drinking water. The results of the analyses are shown in Table 3. The MDMC-3 bed allowed iron removal from the water much lower than the level of $0.2 \mathrm{mg} / \mathrm{L}$. Man- ganese was also successfully removed to the level of $<0.05 \mathrm{mg} / \mathrm{L}$. In the process of filtration the decrease in colour and turbidity was also observed. It shows the lack of the bed influence on the $\mathrm{pH}$ of the water which would fall outside its buffering capacity.

The filter filled with the MDMC-3 material was characterized by very high effectiveness of the iron removal on the level of $96-100 \%$. Figures $2 a$ and $2 b$ present the distribution of concentration of iron in water in the filtration bed profile for the two filtration cycles. It can be observed that the majority of the iron is entrapped in the upper layer which thickness is $10-20 \mathrm{~cm}$, and the zone of iron removal reaches the maximum depth of $30 \mathrm{~cm}$. Iron removal took place partially due to filtration of its oxidized forms but it was also the result of chemical activity of $\mathrm{MnO}_{2}$ because the zone of the iron removal was small and its depth did not change significantly. The average mass capacity $M C_{F e}$ of the bed for the layer of active iron removal $(20 \mathrm{~cm})$ was $4986 \mathrm{~g}$ $\mathrm{Fe} / \mathrm{m}^{3}$ of the bed.

During the run of the filtration cycle the filtration rate decreased and the bed

TABLE 3. Average quality parameters of the raw water and the water treated in the following filtrating cycles

\begin{tabular}{|c|c|c|c|c|c|c|c|c|c|c|}
\hline \multirow{2}{*}{$\begin{array}{l}\text { Filtration } \\
\text { cycles }\end{array}$} & \multicolumn{2}{|c|}{$\begin{array}{c}\text { Iron } \\
{[\mathrm{mg} / \mathrm{L}]}\end{array}$} & \multicolumn{2}{c|}{$\begin{array}{c}\text { Manganese } \\
{[\mathrm{mg} / \mathrm{L}]}\end{array}$} & \multicolumn{2}{c|}{$\begin{array}{c}\text { Hydrogen ions } \\
{[\mathrm{pH}]}\end{array}$} & \multicolumn{2}{c|}{$\begin{array}{c}\text { True colour } \\
{[\mathrm{mg} \text { Pt/L] }}\end{array}$} & \multicolumn{2}{c|}{$\begin{array}{c}\text { Turbidity } \\
{[\mathrm{NTU}]}\end{array}$} \\
\cline { 2 - 12 } & $\begin{array}{c}\text { raw } \\
\text { water }\end{array}$ & $\begin{array}{c}\text { treated } \\
\text { water }\end{array}$ & $\begin{array}{c}\text { raw } \\
\text { water }\end{array}$ & $\begin{array}{c}\text { treated } \\
\text { water }\end{array}$ & $\begin{array}{c}\text { raw } \\
\text { water }\end{array}$ & $\begin{array}{c}\text { treated } \\
\text { water }\end{array}$ & $\begin{array}{c}\text { raw } \\
\text { water }\end{array}$ & $\begin{array}{c}\text { treated } \\
\text { water }\end{array}$ & $\begin{array}{c}\text { raw } \\
\text { water }\end{array}$ & $\begin{array}{c}\text { treated } \\
\text { water }\end{array}$ \\
\hline 1 & 2.67 & 0.03 & 0.26 & 0.01 & 7.2 & 7.2 & 19 & 5 & 1.12 & 0.29 \\
\hline 2 & 2.70 & 0.04 & 0.33 & 0.03 & 7.2 & 7.2 & 17 & 2 & 0.78 & 0.18 \\
\hline 3 & 2.46 & 0.05 & 0.32 & 0.02 & 7.2 & 7.2 & 18 & 2 & 0.96 & 0.19 \\
\hline 4 & 3.01 & 0.06 & 0.30 & 0.01 & 7.1 & 7.2 & 24 & 4 & 1.33 & 0.37 \\
\hline 5 & 2.56 & 0.03 & 0.24 & 0.01 & 7.1 & 7.1 & 14 & 2 & 0.85 & 0.17 \\
\hline 6 & 2.75 & 0.03 & 0.29 & 0.03 & 7.1 & 7.1 & 21 & 3 & 1.57 & 0.46 \\
\hline
\end{tabular}


a

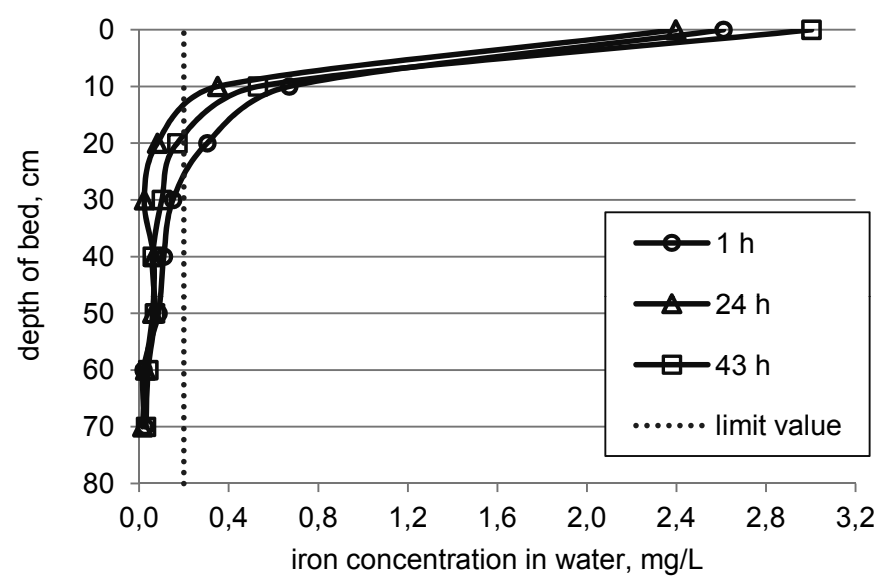

b

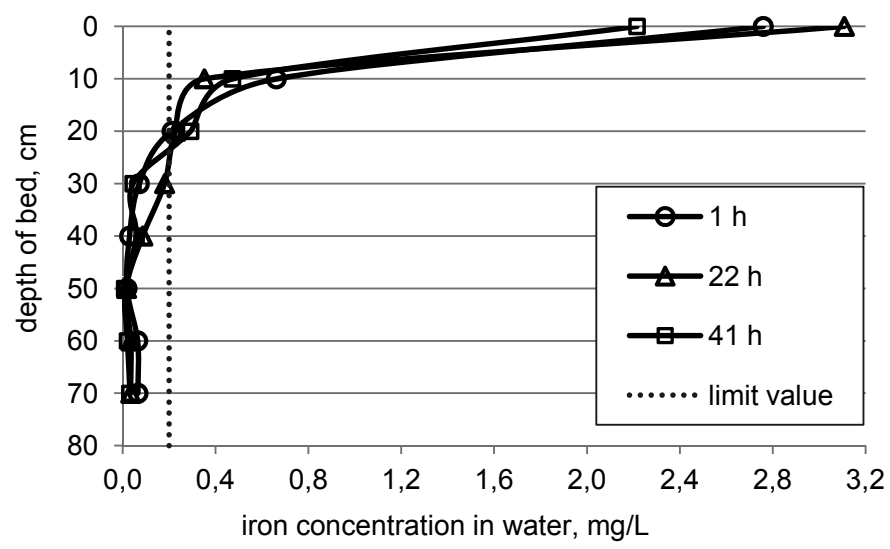

FIGURE 2. Concentration distribution of iron in the filtrate in the profile of filtration bed for two example filtration cycles

was subjected to clogging. The washing process allowed restoring the initial properties of the filter. The values of the head losses in each filtration bed layers was presented in Figures $3 a$ and $3 b$. The maximal head losses appeared in the bed's upper layer of $30 \mathrm{~cm}$ thick and were caused by the bed clogging with oxidized iron and by the compression of the finest fractions in the filtration material during the water filtration (Siwiec
2010). It is possible to notice that the head loss at the beginning of the filtration cycle $(1 \mathrm{~h})$ is small, about $1-2 \mathrm{~cm}$ $\mathrm{H}_{2} \mathrm{O}$. It testifies the effectiveness of the applied washing method (Siwiec 2007; Siwiec 2008). As a result of clogging the head loss increases with the duration of the filtration cycle.

In the filtration bed filled with MDMC-3 the process of iron removal goes along with the process of manganese removal 

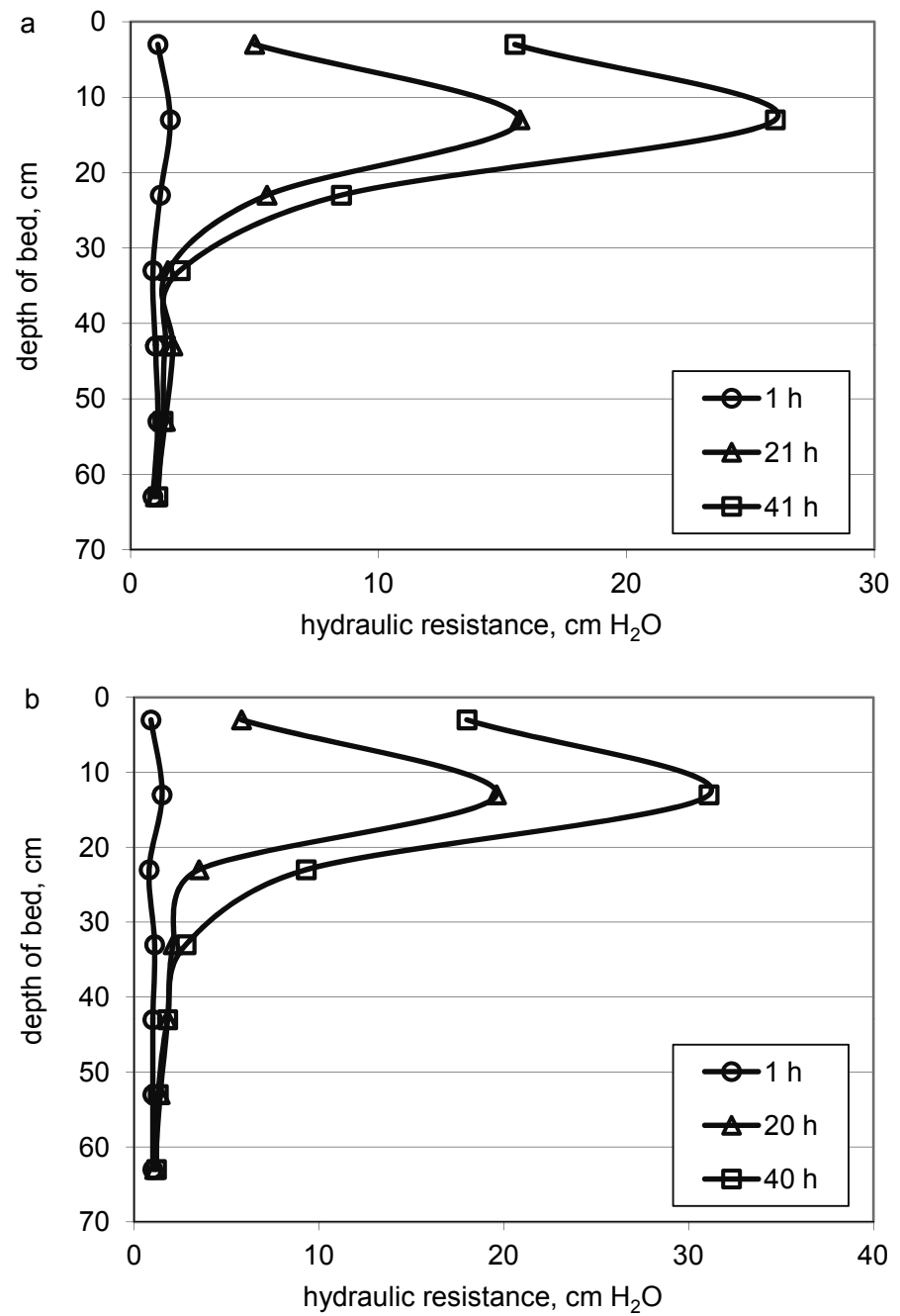

FIGURE 3. Distribution of hydraulic resistance values in the profile of filtration bed for two example filtration cycles

which effectiveness reached $85-100 \%$. Figure $4 \mathrm{a}$ and $4 \mathrm{~b}$ show the concentration distribution of manganese in the filtration bed profile. It is clearly seen that the upper ten-centimeter-layer occupied by the iron compounds does not take part in manganese removal. The zone of active manganese removal is formed beneath the zone of iron removal. In Figures $4 a$ and $4 b$ the displacement of the zone of manganese removal downwards the bed's profile is seen, it is caused by exhaustion of the sorption capacity of the material in the following hours of the experiment. The mass capacity $M C_{M n}$ of the filter was $670 \mathrm{~g} \mathrm{Mn} / \mathrm{m}^{3}$ of the bed $(0.51 \mathrm{mg} \mathrm{Mn} / \mathrm{g}$ of the bed). The maximum sorption capacity $q_{m}$ MDMC-3 was not used because the end of the filtration cycle depended on the extension of the 
a

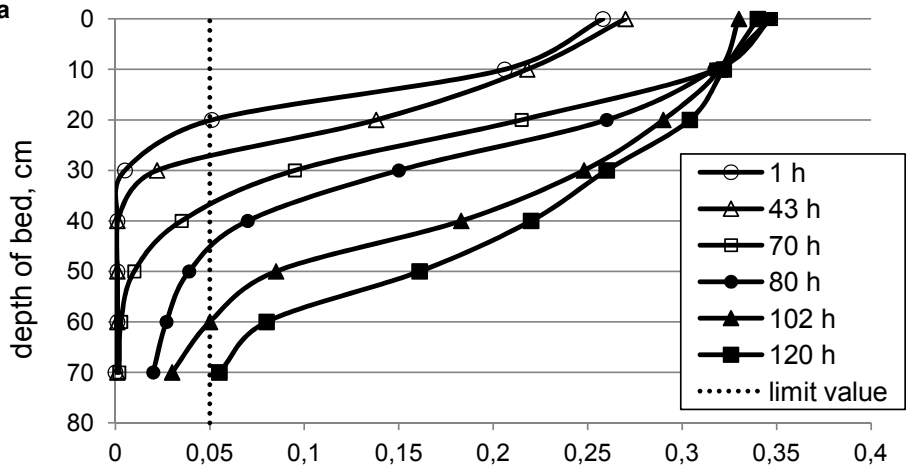

manganese(II) concentration in water, $\mathrm{mg} / \mathrm{L}$

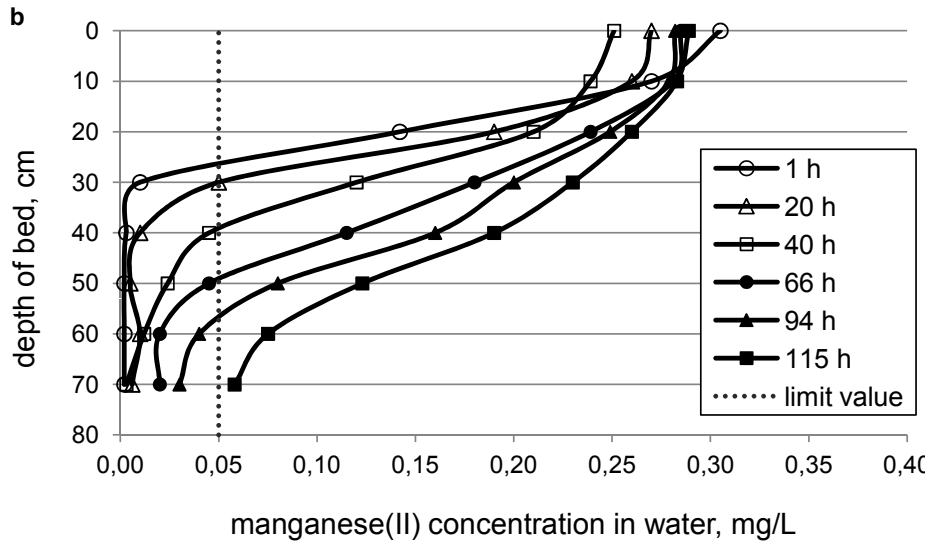

FIGURE 4. Concentration distribution of manganese in the filtrate in the profile of filtration bed

limit values of drinking water quality parameters (Directive 98/83/WE). In this case it was the manganese concentration on the level of $0.05 \mathrm{mg} / \mathrm{L}$. That is why the mass capacity $M C_{M n}$ of MDMC-3 is only half of the value of $q_{m}$ determined in the sorption experiment. Another reason for this can be the occupation of the active centers by the organic compounds present in the water and ammonium cation, as well as high water hardness which inhibits the manganese removal process. The MDMC-3 material was subjected to regeneration which allowed reinstated its sorption capacity and the ability to
manganese(II) oxidizing. The MDMC-3 material was compared to Greensand Plus material regarding its effectiveness for water treatment. The Greensand Plus is a material for underground water treatment and according to the manufacturer's information it is characterized by the following mass capacities: $19 \mathrm{~g} \mathrm{Mn} / \mathrm{ft}^{3}$ of the bed $\left(671 \mathrm{~g} \mathrm{Mn} / \mathrm{m}^{3}\right)$ and $38 \mathrm{~g} \mathrm{Fe} /$ $/ \mathrm{ft}^{3}$ (1343 $\left.\mathrm{g} \mathrm{Fe} / \mathrm{m}^{3}\right)$ (Melstream...). The capacities of both filtration materials to manganese removal are the same; however, the effectiveness of iron removal is two times higher for MDMC-3. It testifies that the MDMC-3 material has 
a high potential as a chemically active and filtration bed for underground water treatment.

\section{CONCLUSIONS}

The modified chalcedonite, the variety MDMC-3, used as a single stage filtration bed with the thickness of $0.7 \mathrm{~m}$ allows effectively treat underground water with the above normal iron and manganese concentration and the increased colour and turbidity. In the filtration bed profile separate zones of active iron and manganese removal are formed. The manganese capacity of the tested material is comparable to the other commercial materials used for underground water treatment, but MDMC-3 bed retains a much larger load of the iron. The use of anthracite as the upper layer which takes the iron charge allowed using MDMC3 completely as the main bed for manganese removal. The manganese dioxide modified chalcedonite (the variety MDMC-3) can be taken into account as effective manganese removing bed in the second stage of the filter or iron-manganese removing bed in a single stage filtration.

\section{REFERENCES}

ANIELAK A.M. 2006: Właściwości fizykochemiczne klinoptylolitu modyfikowanego ditlenkiem manganu [The Physicochemical Properties of Manganese Dioxide-modified Clinoptylolite]. Przem. Chem. 85, 487-491 [Engl. summ.].

Directive 98/83/WE of November 1998 on water quality intended for human consumption.
GAJOWY E., GAJOWY M., ILECKI W. 2004: Poprawa efektywności usuwania jonów żelaza i manganu przy uzdatnianiu wód podziemnych na małych stacjach uzdatniania wody [The improvement of iron and manganese removal in the small water treatment plants]. Materials of $\mathrm{VI}^{\text {th }}$ International Conference "Water Supply and Water Quality" Poznań, Poland, T. 1, 529-540.

KALETA J., PAPCIAK D., PUSZKAREWICZ A. 2009: Naturalne i modyfikowane minerały w uzdatnianiu wód podziemnych [Natural and modified minerals in remediation of groundwater]. Gosp. Sur. Min. 25, 51-63 [Engl. summ.].

KOWAL A.L., ŚWIDERSKA-BRÓŻ M. 2009: Oczyszczanie wody. Podstawy teoretyczne i technologiczne, procesy $i$ urzqdzenia. Wyd. Nauk. PWN, Warszawa.

Melstream webpage (http://www.melstream. com/resources/FMH\%20Data\%20Sheet. pdf (Accessed: 02.04.2012)

MICHEL M.M. 2011: Charakterystyka chalcedonitu ze złoża Teofilów pod kątem możliwości wykorzystania $\mathrm{w}$ technologii uzdatniania wody i oczyszczania ścieków [Characteristics of chalcedonite from Teofilów deposit for possible use in technology of water and wastewater treatment]. Gosp. Sur. Min. 27, 49-67 [Engl. summ.].

MICHEL M.M. 2012: A study of application of chalcedonite as a manganese dioxide carrier. Ann. Warsaw Univ. of Life Sci. - SGGW, Land Reclam. 44 (1), 63-73.

MICHEL M.M, KIEDRYŃSKA L. 2011: Modelling equilibrium data for manganese (II) sorption onto manganese dioxide modified chalcedonite using the nonlinear regression method. Ann. Warsaw Univ. of Life Sci. - SGGW, Land Reclam. 43 (2), 155-163.

MICHEL M.M, KIEDRYŃSKA L. 2012: Usuwanie manganu(II) na chalcedonicie modyfikowanym tlenkiem manganu(IV) [Removal of manganese(II) by sorption on manganese-dioxide-modified chalcedonite]. Przem. Chem. 91/7, 1416-1419 [Engl. summ.]. 
Mikrosil webpage http://www.mikrosil.com. $\mathrm{pl} /$ index.php/referencje-wdrozenia (Accessed: 05.04.2012).

SIWIEC T. 2007: Warunki ptukania jednowarstwowych $i$ dwuwarstwowych filtrów pospiesznych [Conditions for backwashing of monolayers and duolayers rapid filters]. Warsaw Univ. Life Sci. Press, Warsaw [Engl. summ.].

SIWIEC T. 2008: Parametry płukania złóż chalcedonitowych [Backwashing parameters of chalcedonite beds]. Materials of VIII ${ }^{\text {th }}$ International Conference "Water Supply and Water Quality" Poznań, Poland, T. 1, 659-670.

SIWIEC T. 2010: Zmiany porowatości międzyziarnowej złoża podczas procesów filtracji i płukania [Changes of void fraction in bed during filtration and backwashing processes]. In: M.M. Sozański [Ed.]. Zaopatrzenie $w$ wodę, jakość iochrona wód-zagadnienia wspótczesne [Water supply and water quality-present issues]. Wyd. PZITiS, Poznań [Engl. summ.].

SOZAŃSKI M.M., JEŻ-WALKOWIAK J., WEBER Ł., SZAMBELAŃCZYK K. 2007: Badania w skali pilotowej i technicznej odżelaziania i odmanganiania wód podziemnych w procesie filtracji przez złoża chalcedonitowe [Pilot and full scale research on iron and manganese removal from groundwater in filtration process through chalcedonit sand]. [Engl. summ.]. Instal 10, 60-64.

WEBER Ł., SZAMBELAŃCZYK K., 2006: Badania technologiczne nad uzdatnianiem wody podziemnej na złożach chalcedonitowych na Stacji Uzdatniania Wody Nowy Folwark. Forum Eksploatatora 1 (22), 31-33.
Streszczenie: Badania nad zastosowaniem modyfikowanego chalcedonitu do uzdatniania wody podziemnej. W artykule przedstawiono wyniki badań nad uzdatnianiem wody podziemnej na chalcedonicie modyfikowanym $\mathrm{MnO}_{2}$ (odmiana MDMC-3). Bateriał badawczy stanowił wypełnienie grawitacyjnego filtra. Woda surowa, ujmowana z poziomu czwartorzędu i napowietrzona w aeratorze ciśnieniowym, dostarczana była na badane złoże filtracyjne $\mathrm{z}$ ciagu technologicznego Naukowo-Badawczej Stacji Wodociagowej SGGW. Obserwowano zarówno obniżenie stężenia żelaza i manganu, jak i barwy i mętności do poziomu określonego w Dyrektywie 98/83/WE. Pojemności masowe złoża filtracyjnego wynosiły $4986 \mathrm{~g} \mathrm{Fe} / \mathrm{m}^{3}$ złoża oraz $670 \mathrm{~g} \mathrm{Mn} / \mathrm{m}^{3}$ złoża. Materiał MDMC-3 można zaklasyfikować jako złoże chemicznie aktywne, ponieważ w trakcie uzdatniania wody traci swoje właściwości utleniająco-sorpcyjne i może być regenerowane za pomocą utleniacza. Efektywną metodą czyszczenia wypełnienia filtracyjnego jest płukanie wodno-powietrzne.

Slowa kluczowe: uzdatnianie wód podziemnych, usuwanie żelaza i manganu, złoża chemicznie aktywne, modyfikowany chalcedonit.

MS. received August 2012

\section{Author's address:}

Magdalena M. Michel

Katedra Inżynierii Budowlanej

Wydział Budownictwa i Inżynierii Środowiska

Szkoła Główna Gospodarstwa Wiejskiego

ul. Nowoursynowska 159

02-776 Warszawa, Poland

e-mail: magdalena_michel@sggw.pl 